JPPIPA, Vol.2 No.2 2017
Jurnal Penelitian Pendidikan IPA
http://journal.unesa.ac.id/index.php/jppipa

\title{
EFEKTIVITAS MODUL IPA BERBASIS ETNOSAINS TERHADAP PENINGKATAN KETERAMPILAN BERPIKIR KRITIS SISWA
}

Oleh:

Nur Intan Fitriani ${ }^{1}$ dan Beni Setiawan ${ }^{2}$

${ }^{1,2}$ Jurusan IPA, Fakultas Matematika dan Ilmu Pengetahuan Alam

Universitas Negeri Surabaya, Indonesia

\begin{abstract}
Abstrak
Penelitian ini bertujuan untuk mendeskripsikan keefektifan modul IPA berbasis etnosains di SMP Negeri 3 Kota Mojokerto. Jenis penelitian ini menggunkaan metode eksperimen dengan desain penelitian Praeksperimental dengan menggunakan rancangan penelitian one group pretes posttest yang merupakan bagian dari penelitian dan pengembangan Research and Development / R\&D) level 4. Penelitian ini diujicobakan terbatas kepada 15 siswa kelas VII-H SMP Negeri 3 Kota Mojokerto. Instrumen yang digunakan dalam penelitian ini antara lain berupa lembar tes keterampilan berpikir kritis, dan lembar angket respons siswa. Teknik pengumpulan data dengan cara metode tes, dan metode angket. Hasil dari penelitian menggunakan modul IPA berbasis etnosains didapatkan bahwa dengan menggunakan perhitungan NGain diperoleh hasil 0,62 yang termasuk kedalam kategori sedang dengan dan hasil angket respons siswa sebesar 95\% dengan kategori sangat baik. Hasil dari penelitian menunjukkan bahwa modul IPA berbasis etnosains secara efektif dapat meningkatkan keterampilan berpikir kritis siswa.
\end{abstract}

Kata Kunci: modul IPA berbasis etnosains, keterampilan berpikir kritis.

\section{Abstract}

This study aims to describe the effectiveness of IPA module based on ethnosains in SMP Negeri 3 Kota Mojokerto. This type of research uses experimental method with Preeksperimental research design using one group pretest posttest research design which is part of Research and Development $/ R \& D$ level 4 research. This research is trialed limited to 15 students of class VII-H SMP Negeri 3 Kota Mojokerto. Instruments used in this study include the form of critical thinking skills test, and student response questionnaire. Data collection techniques by means of test methods, and questionnaire methods. The result of research using IPN module based on ethnosciences was obtained that by using $\mathrm{N}$-Gain calculation, it was found that 0.62 results were included in the moderate category and the students' response result was $95 \%$ with very good category. The results of the study show that the IPA module based on ethnosciences can effectively improve students' critical thinking skills.

Keywords: IPA module based on ethnoscience and critical thinking skills

(C) 2017 Universitas Negeri Surabaya

\footnotetext{
1,2 Alamat Korespondensi:

Jurusan IPA, Fakultas MIPA, Universitas Negeri Surabaya

Gedung $\mathrm{C} 12$

E-mail: nurintan555@gmail.com
}

p-ISSN: 2527-7537

e-ISSN: 2549-2209 


\section{PENDAHULUAN}

Pendidikan memiliki keterkaitan dengan perkembangan globalisasi yang mengalami perkembangan yang sangat cepat sehingga aspek pendidikan juga mengalami perkembangan. Salah satu bukti perkembangan zaman yang sekarang dialami negara Indonesia yaitu adanya tantangan di abad 21 atau yang lebih dikenal dengan 21st century skill. Menghadapi hal tersebut pemerintah mengharuskan siswa memiliki beberapa dimensi keterampilan yang meliputi kreatif, kritis, produktif, mandiri, kolaborasi, dan komunikatif (Permendikbud, 2016).

Berpikir kritis mempunyai peranan penting dalam dunia pendidikan dan merupakan tujuan utama dalam pembelajaran karena dengan kemampuan berpikir kritis yang memadai, siswa tidak hanya dapat menguasai isi dari setiap mata pelajaran yang dipelajarinya tetapi juga akan dapat mengaplikasikannya dalam kehidupan sehari-hari. Namun dengan berkembangnya dunia pendidikan bukan berarti kemampuan IPA negara Indonesia memiliki skor yang tinggi secara mendunia. Hal tersebut dibuktikan dengan hasil laporan PISA tahun 2015 yang menyatakan bahwa kemampuan IPA negara Indonesia menempati urutan ke-69 dari 76 negara (Kemendikbud, 2016). Menurut Purwanto (dalam Hendikwati, 2011) penyebab rendahnya kemampuan IPA dipengaruhi oleh dua faktor yaitu faktor internal yang salahsatunya yaitu kemampuan kognitif siswa dan faktor eksternal yang salah satunya yaitu keterbatasan sarana bagi siswa.

Sarana pembelajaran merupakan peralatan dan perlengkapan yang secara langsung dipergunakan dan menunjang proses pendidikan salah satunya merupakan penggunaan bahan ajar. Kemampuan berpikir kritis siswa dalam pembelajaran dapat dipengaruhi oleh bahan ajar karena bahan ajar yang belum melibatkan siswa aktif dalam pembelajaran dapat menyebabkan kurang maksimalnya kemampuan berpikir kritis (Prastowo, 2014). Selain itu, Kemendikbud pada tahun 2012, mengharapkan setiap pembelajaran termasuk IPA dapat memanfaatkan budaya dan kearifan lokal yang ada di lingkungan sekitar sebagai sumber belajar dimana pengetahuan-pengetahuan yang ada di masyarakat terintegrasi dalam suatu budaya dapat dikaitkan dengan konsep-konsep IPA ketika pembelajaran berlangsung.

Berdasarkan hasil angket yang diberikan, sebanyak $81 \%$ siswa menyatakan bahwa bahan ajar yang digunakan selama ini masih menggunakan bahan ajar yang sudah tersedia, selain itu angket juga menunjukkan bahwa sebesar $81 \%$ siswa menyatakan bahwa bahan ajar yang telah digunakan belum dikaitkan dengan budaya lokal di sekitar tempat tinggal mereka. Padahal, sebanyak
91\% siswa menyatakan bahwa di daerah tempat tinggal mereka memiliki potensi budaya yang sangat terkenal yaitu batik tulis. Hal tersebut menunjukan bahwa adanya kemampuan berpikir kritis siswa dapat dipengaruhi oleh faktor bahan ajar yang dalam proses pembelajaran belum dikaitkan dengan budaya lokal setempat.

Dari sisi keterampilan berfikir kritis siswa kelas VII-H dapat diketahui setelah dilakukan uji coba soal yang diberikan. Hasil menunjukkan bahwa siswa mampu menginterpretasi sebanyak $60 \%$, menganalisis $47 \%$, mengevaluasi $31 \%$, menarik kesimpulan 38\%, dan menjelaskan 53\%.

Berdasarkan pernyataan tersebut maka upaya meningkatkan keterampilan berpikir kritis siswa dapat dilakukan dengan cara mengembangkan bahan ajar yang berbasis etnosains. Menurut Hayati (dalam Pratiwi, dkk, 2014) mengungkapkan bahwa modul dapat meningkatkan keterampilan berpikir kritis karena siswa dapat belajar secara mandiri sehingga memungkinkan siswa untuk meningkatkan aktifitas siswa sesuai dengan kemampuan dan kemajuan masing-masing. Dengan demikian salah satu upaya untuk meningkatkan keterampilan berpikir kritis siswa dapat dilakukan dengan mengembangkan modul IPA berbasis etnosains.

Penelitian relevan yang pernah dilakukan oleh beberapa peneliti antara lain oleh Yanti, dkk (2015) menunjukkan bahwa modul pembelajaran fisika untuk SMA dapat meningkatkan kemampuan berpikir kritis siswa sebesar 39\%. Penelitian Innatesari (2016) menunjukkan bahwa modul IPA berbasis Local Wisdom memperoleh layak digunakan secara teoritis dalam pembelajaran. Arfianawati, dkk (2016) menunjukkan bahwa model pembelajaran kimia berbasis etnosains dapat meningkatkan hasil bejar siswa sebesar 40,1\% dan kemampuan berpikir kritis sebesar 17,0\%. Adapun perbedaan penelitian yang dilakukan dibanding penelitian yang relevan yaitu peneliti mengembangkan modul IPA berbasis etnosains untuk meningkatkan keterampilan berpikir kritis siswa.

Penelitian ini dilakukan dengan menggunakan materi kelas VII yaitu klasifikasi materi dan perubahannya.

Berdasarkan uraian di atas, tujuan dari penelitian ini yaitu mendeskripsikan efektivitas modul IPA berbasis etnosains yang diperoleh dari hasil tes keterampilan berpikir kritis dan angket respons siswa.

\section{METODE}

Jenis penelitian ini menggunkaan metode eksperimen dengan desain penelitian Praeksperimental dengan menggunakan rancangan penelitian one group pretes posttest yang 
merupakan bagian dari penelitian dan pengembangan Research and Development (R\&D) level 4 menurut Sugiyono (2015). Subjek dari penelitian ini adalah modul IPA berbasis etnosains untuk meningkatkan keterampilan berpikir kritis siswa SMP pada materi klasifikasi materi dan perubahannya yang diujicobakan pada 15 siswa kelas VII-H SMP Negeri 3 Kota Mojokerto.

Instrumen yang digunakan dalam penelitian ini berupa lembar tes keterampilan berpikir kritis siswa, dan lembar angket respos siswa. Teknik pengumpulan data berupa metode tes dan metode angket, sedangkan teknik analisis data berupa analaisis data hasil tes keterampilan berpikir kritis dan angket respons siswa.

Penilaian keefektifan modul IPA berbasis etnosains diperoleh berdasarkan peningkatan keterampilan berpikir kritis siswa dan angket respons siswa yang kemudian dianalisis. Analisis data tes berpikir kritis diperoleh dengan menggunakan rumus:

$$
\text { nilai }=\frac{\text { skor yang diperoleh }}{\text { skor maksimum }} \times 100 \%
$$

yang selanjutnya diinterpretasikan berdasarkan skala menurut Riduwan. Siswa dinyatakan memiliki kemampuan berpikir kritis apabila mencapai persentase 51\%-100\%, sedangkan untuk peningkatan keterampilan berpikir kritis diperoleh dengan persamaan berikut.

$$
<g>=\frac{\mathrm{S}_{\mathrm{f}}-\mathrm{S}_{\mathrm{i}}}{\mathrm{S}_{\text {maks }}-\mathrm{S}_{\mathrm{i}}} \times 100 \%
$$

dengan:

$\mathrm{S}_{\mathrm{f}}=$ skor final

$\mathrm{S}_{\mathrm{i}}=$ skor initial

$\mathrm{S}_{\mathrm{maks}}=$ skor maksimum yang mungkin dicapai

\section{HASIL DAN PEMBAHASAN}

Keefektifan modul IPA berbasis etnosains yang dikembangkan ditinjau dari peningkatan keterampilan berpikir kritis siswa dan hasil angket respons siswa. Peningkatan keterampilan berpikir kritis diperoleh dari nilai pretest dan posttest, sedangkan hasil angket respons siswa diperoleh dari lembar angket respons yang diberikan kepada 15 siswa setelah melakukan pembelajaran dengan menggunakan modul IPA berbasis etnosains yang dikembangkan.

Soal pretest dan posttest yang diberikan kepada siswa terdiri dari 10 soal uraian yang berorientasi keterampilan berpikir kritis. Jenis keterampilan berpikir kritis yang menjadi penilaian antara lain menginterpretasi, menganalisis, mengevaluasi, menarik kesimpulan, dan penjelasan dengan menggunakan modul IPA-etnosains. Pada Tabel 1 disajikan rekapitulasi hasil pretest dan posttest keterampilan berpikir kritis siswa kelas VII-H SMP Negeri 3 Kota Mojokerto.

Tabel 1. Rekapitulasi Skor N-Gain

\begin{tabular}{ccccc}
\hline Nama & Pretest & Posttest & N-Gain & Kriteria \\
\hline Siswa A & 38 & 81 & 0,69 & Sedang \\
Siswa B & 52 & 83 & 0,65 & Sedang \\
Siswa C & 48 & 86 & 0,73 & Tinggi \\
Siswa D & 45 & 83 & 0,69 & Sedang \\
Siswa E & 43 & 79 & 0,63 & Sedang \\
Siswa F & 50 & 81 & 0,62 & Sedang \\
Siswa G & 48 & 76 & 0,54 & Sedang \\
Siswa H & 43 & 69 & 0,46 & Sedang \\
Siswa I & 60 & 79 & 0,48 & Sedang \\
Siswa J & 76 & 88 & 0,50 & Sedang \\
Siswa K & 45 & 81 & 0,65 & Sedang \\
Siswa L & 64 & 90 & 0,72 & Tinggi \\
Siswa M & 43 & 83 & 0,70 & Tinggi \\
Siswa N & 50 & 81 & 0,62 & Sedang \\
Siswa O & 52 & 81 & 0,60 & Sedang \\
\hline Nilai rata-rata & 50 & 81 & 0,62 & Sedang \\
\hline
\end{tabular}


Tabel 1 di atas menunjukkan adanya peningkatan keterampilan berpikir kritis siswa yang dilihat dari nilai N-Gain setiap siswa. Secara umum dapat diketahui bahwa sebanyak 12 siswa mendapatkan nilai gain kategori sedang dan ada 3 siswa yang mendapat gain kategori tinggi. Berikut tabel ketuntasan pretest dan posttest siswa. Adapun diagram peningkatan keterampilan berpikir kritis disajikan dalam Gambar 1 berikut.

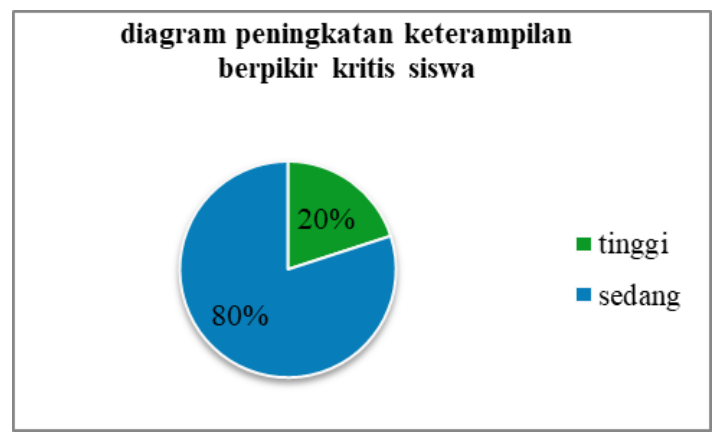

Gambar 1. Diagram Peningkatan Keterampilan Berpikir Kritis Siswa
Gambar 1 menunjukkan bahwa peningkatan keterampilan berpikir kritis siswa didominasi oleh peningkatan dengan kategori sedang yaitu sebanyak $80 \%$, sedangkan peningkatan dengan kategori tinggi sebesar $20 \%$ dari siswa yang mengikuti pretest dan posttest.

Perolehan skor N-Gain tinggi dan rendah di atas diperoleh berdasarkan nilai pretest dan posttest. Rata-rata skor N-Gain diperoleh sebesar 0,62 yang termasuk kedalam kategori sedang. Kategori peningkatan berdasarkan skor N-Gain meunjukkan bahwa pembelajaran menggunakan modul IPA berjalan secara efektif dikarenakan tidak terdapat hasil skor yang rendah (Hake, 1999). Apabila ditinjau dari N-Gain tiap aspek keterampilan berpikir kritis dihasilkan data sebagai berikut.

Hal ini sesuai dengan penelitian yang telah dilakukan oleh Susana, dkk mengenai pengembangan modul IPA terpadu berbasis berpikir kritis yang didapatkan hasil perolehan $\mathrm{N}$ Gain ternormalisasi sedang dan kemampuan berpikir kritis dengan kategori baik.

Tabel 2. Ketercapaian Tiap Aspek Keterampilan Berpikir Kritis

\begin{tabular}{lcccc}
\hline \multirow{1}{*}{$\begin{array}{c}\text { Aspek yang } \\
\text { diamati }\end{array}$} & \multicolumn{2}{c}{$\begin{array}{c}\text { Presentase } \\
\text { ketercapaian }\end{array}$} & Gain & Kategori \\
\cline { 2 - 3 } & Pre-test & Post-test & & \\
\hline Menginterpretasi & 68 & 88 & 0,63 & Sedang \\
Menganalisis & 57 & 79 & 0,51 & Sedang \\
Mengevaluasi & 48 & 73 & 0,48 & Sedang \\
Menarik & 35 & 77 & 0,65 & Sedang \\
Kesimpulan & 60 & 87 & 0,68 & Sedang \\
Penjelasan & 50 & 82 & & \\
\hline \multicolumn{1}{c}{ Rata-rata } & \multicolumn{2}{c}{} & &
\end{tabular}

Berdasarkan tabel di atas menunjukkan bahwa skor N-Gain terendah yaitu pada aspek evaluasi dan skor tertinggi terdapat pada aspek penjelasan, meskipun dalam kelima aspek yang diamati mendapat kategori yang sama yaitu sedang.

Perbedaan tersebut dapat disebabkan karena adanya hasil nilai yang diperoleh siswa. Nilai siswa yang belum mencapai ketuntasan yaitu siswa $\mathrm{H}$. Siswa $\mathrm{H}$ mendapat nilai pretest yaitu 43 sedangkan pada posttest mendapat nilai sebesar 69. Adapun persentase setiap keterampilan berpikir kritis yang diperoleh siswa $\mathrm{H}$ pada saat pretest antara lain menginterpretasi sebesar $67 \%$, menganalisis $50 \%$, mengevaluasi $40 \%$, menarik kesimpulan $25 \%$, dan penjelasan $50 \%$, sedangkan posttest diperoleh hasil menginterpretasi $83 \%$, menganalisis $100 \%$, mengevaluasi $40 \%$, menarik kesimpulan $60 \%$, dan penjelasan $83 \%$. Ketidaktuntasan yang terjadi pada siswa $\mathrm{H}$ dikarenakan siswa tersebut memiliki ratarata keterampilan berpikir kritis sebesar $73 \%$ dengan kategori cukup kritis sehingga nilai posttest yang diperoleh belum melebihi KKM.

Berdasarkan persentase di atas, diperoleh hasil terendah yaitu keterampilan berpikir kritis evaluasi. Evaluasi merupakan salah satu keterampilan berpikir kritis yang harus dimiliki oleh siswa. Siswa yang belum memiliki keterampilan berpikir kritis maka siswa tidak akan dapat melakukan proses pengorganisasian buktibukti solusi masalah sehingga cenderung menyebabkan peroleh nilai siswa menjadi rendah (Kurniawati, 2008).

Berbeda halnya dengan siswa A yang mengalami kesulitan ketika mengerjakan pretest dengan nilai 38 dengan persentase keterampilan berpikir kritis antara lain menginterpretasi sebesar 
$83 \%$, menganalisis sebesar $50 \%$, mengevaluasi $30 \%$, menarik kesimpulan $25 \%$, dan pejelasan sebesar $33 \%$. Hal tersebut berbeda dengan hasil posttest, ketika mengerjakan postest mendapatkan nilai mencapai ketuntasan yaitu sebesar 81 yang termasuk kedalam kriteria sangat kritis dengan gain 0,69 termasuk kategori sedang. Adapaun persentase keterampilan berpikir kritis pada saat posttest antara lain menganalisis $83 \%$, menganalisis $88 \%$, mengevaluasi $60 \%$, menarik kesimpulan $83 \%$, dan penjelasan $100 \%$.

Berdasarkan persentase di atas, diperoleh ratarata sebesar $83 \%$ yang termasuk kategori sangat kritis. Hasil tersebut menunjukkan bahwa keterampilan berpikir kritis siswa A mempengaruhi nilai posttest yang diperolehnya. Siswa yang memiliki keterampilan berpikir kritis tidak hanya dapat menguasai isi dari setiap mata pelajaran yang dipelajarinya, tetapi juga dapat mengaplikasikannya dalam kehidupan sehari-hari (Sutrisno, 2012).

Meskipun melalui nilai N-Gain kedua siswa tersebut termasuk kedalam kategori yang sama namun siswa A memiliki skor gain yang lebih tinggi dibandingkan siswa H. Selain itu, siswa A merupakan siswa yang memiliki peningkatan tertinggi dari nilai pretest ke posttest yaitu sebesar 43. Data yang muncul ketika pembelajaran ini sesuai dengan pendapat Hayati (dalam Pratiwi, dkk, 2014) yang menyatakan bahwa pengembangan modul dapat meningkatkan keterampilan berpikir kritis karena dalam modul terdapat beberapa keunggulan yang dapat menjadikan siswa lebih bertanggung jawab serta memungkinkan siswa untuk meningkatkan aktifitas belajar optimal sesuai dengan tingkat kemajuan dan kemampuan yang diperoleh selama proses belajar. Selain itu respon siswa yang menyatakan bahwa "modul IPA ini memudahkan saya untuk melakukan kegiatan pemikiran yang lebih tinggi (berpikir kritis)" dengan perolehan skor sempurna juga turut mendukung pendapat tersebut.

Selain dari peningkatan keterampilan berpikir kritis, keefektifan juga ditinjau dari hasil angket respons siswa. Berikut merupakan tabel hasil rekapitulasi data hasil angket respons siswa.

Tabel 3. Rekapitulasi Data Hasil Angket Respons Siswa

\begin{tabular}{|c|c|c|}
\hline No. & Aspek yang dinilai & Nilai $(\%)$ \\
\hline 1. & Modul ini menarik. & $100 \%$ \\
\hline 2. & Tujuan pembelajaran di setiap modul IPA ini jelas. & $100 \%$ \\
\hline 3. & $\begin{array}{l}\text { Langkah-langkah percobaan dalam modul IPA ini mudah } \\
\text { dipahami. }\end{array}$ & $87 \%$ \\
\hline 4. & Pertanyaan-pertanyaan dalam modul IPA ini mudah dimengerti. & $87 \%$ \\
\hline 5. & Modul IPA ini membangkitkan motivasi untuk belajar. & $100 \%$ \\
\hline 6. & Modul IPA ini disajikan dengan berwarna dan dilengkapi gambar. & $100 \%$ \\
\hline 7. & Modul IPA ini sesuai materi yang diajarkan di sekolah. & $73 \%$ \\
\hline 8. & $\begin{array}{l}\text { Modul IPA ini melibatkan fenomena-fenomena dalam kehidupan } \\
\text { sehari-hari. }\end{array}$ & $100 \%$ \\
\hline 9. & $\begin{array}{l}\text { Modul IPA ini memudahkan saya untuk melakukan kegiatan } \\
\text { pemikiran yang lebih tinggi (berpikir kritis) }\end{array}$ & $100 \%$ \\
\hline 10. & $\begin{array}{l}\text { Modul ini memiliki keterampilan berpikir kritis menginterpretasi, } \\
\text { menganalisis, mengevaluasi, menarik kesimpulan dan penjelasan }\end{array}$ & $100 \%$ \\
\hline & Nilai secara keseluruhan angket respons siswa & $95 \%$ \\
\hline & Kriteria & Sangat baik \\
\hline
\end{tabular}

Berdasarkan tabel 3 di atas menunnjukkan bahwa pernyataan "modul IPA ini sesuai materi yang diajarkan di sekolah" memperoleh persentase paling rendah. Hal tersebut disebabkan karena belum adanya buku atau sarana pembelajaran yang dikaitkan dengan budaya di sekitar tempat tinggal siswa, pernyataan tersebut sesuai dengan angket pretest yang disebarkan kepada siswa di mana banyak siswa yang menyatakan bahwa di sekolah belum pernah ada buku penunjang yang mengkaitkan budaya dengan pembelajaran. Hal tersebut menunjukkan bahwa kegiatan pembelajaran di sekolah belum sesuai dengan tuntutan Kurikulum 2013 yang mana kurikulum 2013 harus tanggap terhadap perkembangan ilmu pengetahuan, budaya, teknologi dan seni yang dapat membangun rasa ingin tahu dan kemampuan peserta didik untuk memanfaatkan secara tepat (Kemendikbud, 2012).

\section{KESIMPULAN}

Berdasarkan hasil penelitian dan kesimpulan di atas, dapat disimpulkan bahwa modul IPA berbasis etnosains pada materi klasifikasi materi dan perubahannya dinyatakan efektif yang ditunjukkan dengan peningkatan keterampilan 
berpikir kritis siswa yang diperoleh berdasarkan hasil pretest dan posttest menggunakan perhitungan gain skor 0,62 yang termasuk kategori sedang dan hasil angket respons siswa sebesar $95 \%$.

\section{SARAN}

Berdasarkan hasil penelitian yang telah dilakukan, terdapat beberapa saran yang diberikan oleh peneliti antara lain:

1. Perlu adanya pengontrolan kemampuan masing-masing siswa agar dapat dipantau kemajuan yang dimiliki oleh maisng-masing siswa.

2. Perlu dikembangkan jenis bahan ajar lain atau bahan ajar lain yang memiliki inovasi baru agar dapat diperoleh hasil efektivitas keterampilan berpikir kritis dengan menggunakan bahan ajar selain modul.

\section{DAFTAR PUSTAKA}

Arfianawati, S., Sudarmin, dan Sumarni, W. 2016. Model Pembelajaran Kimia Berbasis Etnosains Untuk Meningkatkan Kemampuan Berpikir Kritis Siswa. Jurnal Pengajaran Matematika dan Ilmu Pengetahuan Alam (Online). Vol. 21 No. 1, (http://fpmipa.upi.edu/journal/v1/index.php /jpmipa/article/ view/669, diakses 5 Januari 2017).

Hake, R. 1999. Analyzing Change/Gain Score, (Online), (http://list.asu.edu, diakses pada 24 Januari 2017).

Hendikwati, Putriaji. 2011. Analisis Faktor yang Mempengaruhi Indeks Prestasi Mahasiswa. Jurnal Matematika Kreatif-Inovatif (Online),

(http://journal.unnes.ac.id/nju/index.php/kr eano/article/view/1243/1291, diakses 4 Januari 2017).

Innatesari, Dian Kurva., Beni Setiawan, Tarzan Purnomo. 2016. Kelayakan Modul IPA Berbasis Local Wisdom dengan Tema Erupsi Gunung Kelud. Jurnal Pendidikan Sains (Online), (http://ejournal.unesa.ac.id/article/20425/3 7/ article.pdf, diakses 25 Januari 2017).
Kemdikbud. 2016. Peringkat dan Capaian PISA Indonesia Mengalami Peningkatan, (Online), (http://www.kemdikbud.go.id/main/blog/2 016/12/peringkat-dan-capaian-pisaindinesia-mengalami-peningkatan, diakses 03 Januari 2017).

Kementerian Pendidikan dan Kebudayaan. 2013. Materi Pelatihan Guru Implementasi Kurikulum 2013 SMP/MTs IPA.

Kurniawati. 2008. Upaya Peningkatan Kemampuan Berpikir Kritis dan Keaktifan Siswa Melalui Penerapan Model Pembelajaran Problem Solving dalam Pembelajaran Matematika (Online) (http://eprints.ums.ac.id/2095/, diakses pada 18 Juli 2017)

Permendikbud. 2016. Peraturan Menteri Pendidikan dan Kebudaaan Nomor 20 Tahun 2016 Tentang Standar Kompetensi Lulusan Pendidikan Dasar dan Menengah. Jakarta: Menteri Pendidikan dan Kebudayaan

Prastowo, A. 2014. Panduan Kreatif Membuat Bahan Ajar Inovatif. Jogjakarta: Diva Press.

Pratiwi, HE., Hadi Suwono, Nursasi Handayani. 2014. Pengembangan Modul Pembelajaran Biologi Berbasis Hybrid Learning untuk Meningkatkan Kemampuan Berpikir Kritis dan Hasil Belajar Siswa Kelas XI. Biologi, (Online) (http://jurnalonline.um.ac.id/data/artikel/artikel5C0786 64CE7FDAFB63596CA5E40E83D1.pdf, diakses 28 Februari 2017)

Sugiyono. 2015. Metode Penelitian Kuantitatif Kualitratif dan $R \& D$. Bandung: Alfabeta.

Sutrisno. 2012. Kreatif Mengembangkan Aktivitas Pembelajaran Berbasis TIK. Jakarta: Referensi.

Yanti, F.A., Sukarmin, Suparmi. 2015. Pengembangan Modul Pembelajaran Fisika SMA/MA Berbasis Masalah untuk Meningkatkan Keterampilan Berpikir Kritis Siswa. Pendidikan IPA. (Online), Vol. 4 No. 3 ,

(http://jurnal.fkip.uns.ac.id/index.php/inkui ri/article/view/7820, diakses 5 Januari 2017). 